\title{
CZECH ECONOMY: FIRST YEAR AFTER THE EU ENTRY
}

\author{
Kamil JANÁČEK, Eva ZAMRAZILOVÁ*
}

\begin{abstract}
:
In 2004, the Czech economy continued in solid growth. Slight acceleration of economic growth was driven in particular by strong investment demand and improving performance of the foreign trade with goods. On the other hand, due to slowdown in real wages, consumer demand weakened.

2004 was the year of turnover in foreign trade which has reported the best results since 1994. The EU entry was an important factor behind the improvement of trade balance - the foreign trade exchange significantly accelerated after the EU accession. The EU entry opened new chances to the exporters, especially small and medium-sized companies could fully use the advantage of the Single Market. With the trade balance improving, the reason for permanently high current account deficit is the growing deficit of income balance as a consequence of strong FDI inflow.

January and May changes in the Value Added Tax brought a temporary speed-up of consumer prices. After the absorption of this increase, since the last quarter of 2004, headline inflation has been declining. Similar to previous years, inflation fell under the CNB target corridor. Record high world prices of oil and metals caused a strong increase of industrial producer prices, however, strong competition between both producers and traders has prevented the spillover to consumer prices.
\end{abstract}

Keywords: economic growth, consumer and producer prices, foreign trade, external balance, labour market

JEL Classification: 011, 052, E20.

\section{Summary and Conclusions}

The full-year growth of $4.4 \%$ represents an acceleration against 2003 (3.2\%). 2004 figures indicate the weakening impact of consumer demand and improving

*) Komerční banka, a.s., P.O.Box 839, Politických vězňů 11, CZ - 11407 Prague 1 (e-mail: kamil_janacek@kb.cz; eva_zamrazilova@kb.cz). 
position of the external sector. Consumption of households rose by $2.0 \%$, which means a significant slowdown in comparison with growth of $4.7 \%$, achieved in 2003 . Weakening of consumer demand was caused in particular by slower growth of real wages (the full-year growth of $3.7 \%$, y/y, has been the lowest result within previous four years). Government consumption fell by $2 \%$ due to increased prudency in public finance. Investment demand rose by robust $7.6 \%$ - the connection with strong export activity has been evident.

Trade with goods influenced the GDP growth positively. Higher growth of exports was not so pronounced in the full-year insight, nevertheless, net exports of goods improved by CZK 43.3 bill. Trade with services had a neutral impact on GDP growth. It is clear that the EU entry was an important factor supporting Czech exports in the second half of the year. The Czech economy has thus gradually become an export-driven one.

Table 1

Main Macroeconomic Indicators

\begin{tabular}{|l|l|r|r|r|r|r|r|r|}
\hline & & \multicolumn{1}{|c|}{1999} & 2000 & \multicolumn{1}{|c|}{2001} & 2002 & 2003 & 2004 & $\mathbf{2 0 0 5 f}$ \\
\hline GDP growth & \%, real & 1.20 & 3.9 & 2.6 & 1.5 & 3.2 & 4.4 & $\mathbf{4 . 0}$ \\
\hline Industrial production & \%, real & -3.10 & 5.8 & 6.8 & 4.8 & 5.8 & 9.9 & $\mathbf{5 . 0}$ \\
\hline Construction output & \%, real & -6.50 & 5.6 & 9.6 & 2.5 & 8.9 & 9.7 & $\mathbf{3 . 0}$ \\
\hline Retail sales & \%, real & 2.10 & 4.6 & 4.3 & 2.7 & 5.0 & 2.5 & $\mathbf{3 . 0}$ \\
\hline Inflation & \%, average & 2.10 & 3.9 & 4.7 & 1.8 & 0.1 & 2.8 & $\mathbf{1 . 5}$ \\
\hline Inflation & \%, e.o.p. & 2.50 & 3.9 & 4.1 & 0.6 & 1.0 & 2.8 & $\mathbf{2 . 0}$ \\
\hline $\begin{array}{l}\text { Industrial producer } \\
\text { prices }\end{array}$ & \%, e.o.p. & 3.40 & 5.0 & 0.8 & -0.7 & 0.9 & 7.7 & $\mathbf{2 . 0}$ \\
\hline Unemployment rate & \%, e.o.p. & 9.40 & 8.8 & 8.9 & 9.8 & 10.3 & 9.5 & $\mathbf{9 . 0}$ \\
\hline Trade balance & CZK bill. & -69.90 & -126.8 & -116.7 & -71.3 & -69.8 & -20.6 & $\mathbf{3 5 . 0}$ \\
\hline Current account & USD bill. & -1.50 & -2.7 & -3.3 & -4.2 & -5.7 & -5.6 & $\mathbf{- 5 . 5}$ \\
\hline Current account & \% of GDP & -2.50 & -4.9 & -5.4 & -5.6 & -6.3 & -5.2 & $\mathbf{- 4 . 5}$ \\
\hline Financial account & USD bill. & 3.10 & 3.8 & 4.5 & 10.6 & 5.6 & 7.0 & $\mathbf{8 . 0}$ \\
\hline Financial account & \% of GDP & 5.20 & 6.9 & 7.5 & 14.4 & 6.2 & 6.6 & $\mathbf{6 . 2}$ \\
\hline State budget & \% of GDP & -1.60 & -2.4 & -2.9 & -1.9 & -4.3 & -3.4 & $\mathbf{- 3 . 7}$ \\
\hline $\begin{array}{l}\text { Official FOREX } \\
\text { reserves }\end{array}$ & USD bill. & 12.90 & 13.1 & 14.5 & 23.7 & 27.0 & 28.4 & $\mathbf{2 8 . 0}$ \\
\hline M2 growth & \%, e.o.p & 8.10 & 6.5 & 12.4 & 3.2 & 7.0 & 4.4 & $\mathbf{6 . 5}$ \\
\hline PRIBOR 3M & \%, average & 6.85 & 5.4 & 5.2 & 3.6 & 2.3 & 2.4 & $\mathbf{1 . 9}$ \\
\hline CZK/EUR & average & 36.88 & 35.6 & 34.1 & 30.8 & 31.8 & 31.9 & $\mathbf{3 1 . 0}$ \\
\hline CZK/USD & average & 34.60 & 38.6 & 38.0 & 32.7 & 28.2 & 25.7 & $\mathbf{2 3 . 0}$ \\
\hline
\end{tabular}

Source: Czech National Bank (CNB), Czech Statistical Office, forecasts by Komercni banka (bold figures).

* As of 2004 , according to the new methodology. 
In 2004, current account deficit amounted to CZK 143.3 bill., down from CZK 160.6 bill. in 2003. Current account deficit thus reached $5.2 \%$ of GDP, which was a notable improvement against $6.3 \%$ in 2003. The decline in current account deficit was caused predominantly by improvement of trade balance. Financial account reached a surplus of CZK 180.9 bill., up from 157.1 bill., a year before. Financial account revealed a recovery of FDI inflows, increased purchases of portfolio investments and a small net inflow of other investments.

In 2004 , the exports rose by $23.8 \%$, the imports increased by $19.2 \%$. The fullyear trade deficit amounted to CZK 20.6 bill.: it was an improvement of CZK 49.2 bill. in comparison with 2003. 2004 result was the best one since 1994. The EU entry was an important factor behind the improvement of trade balance. The foreign trade significantly accelerated after the EU accession. The exports increased by $16.3 \%$, January to April 2004, accelerating to $27.4 \%$, May to December. The acceleration of exports thus amounted to more than 10 percentage points, after the EU accession. The increase of imports was less pronounced: imports increased by $20.8 \%$, May to December, after growth of $15.8 \%$, January to April 2004. The EU entry opened new chances to the exporters, especially small and medium-sized companies could fully use the advantage of the Single EU Market. It seems probable that not only the administrative barriers but also the psychological ones were eliminated.

Czech industry witnessed robust growth in 2004. The growth of industrial output accelerated to $9.9 \%$ up from $5.8 \%$ in 2003. Growth in industry was concentrated to manufacturing industries, which rose by $10.8 \%$. Raw material industries contracted by $0.9 \%$. Industry continued to be driven in particular by the exports, especially by the export-oriented companies under foreign control. The direct export sales rose by $17.0 \%$, their share on total industrial sales reaching $49.1 \%$. Direct export sales accelerated after the EU accession: May - December 2004, the growth of direct export sales amounted to $19 \%$, after a growth of $12.9 \%$, January to April.

Both total sales and direct export sales continued to grow more rapidly in the segment of foreign-controlled companies. The companies under foreign control are primarily export oriented - direct export sales accounted for $72.8 \%$ of their total sales. Foreign controlled companies continue to be the major driving force of the Czech industrial output and exports.

The full year growth of construction output amounted to $9.7 \%$, in 2004, which has been the best result since 1993. However, the growth was concentrated to the first four months of the year, when extremely strong activity of the second half of 2003 continued due to expected change of VAT. May to December 2004, the construction output rose by merely $2.6 \%$, after a growth of $27 \%$, January to April 2004 .

Growth in construction was driven especially by large building and civil engineering projects (highways, railway corridors, Prague metro and tram lines, business, distribution and logistic centres). Similar to industry, activities of foreign investors had a positive impact, supporting in particular construction of business centres and assembly halls.

In European context, the share of housing on total construction output has still been quite low (12.6\%). In 2004, construction of 40 thousands new flats was permitted (39 thousands in 2003). In housing construction, mortgage market has been playing a key role. Number of mortgages continued to grow (30\%), however by a slower pace than in 2003 (50\%). Similarly, their value increased by $43 \%$ in 2004, after growth of $57 \%$ in 2003.

In 2004 , retail sales registered a notable slowdown to $2.5 \%$, after a robust $5 \%$ growth in 2003. At the same time, this has been the lowest figure since 1998. Along with slowdown in retail trade, also overall consumer demand weakened in the course of 2004 . The main reason behind weak retail trade results in 2004 was the auto- 
motive segment with growth of $1.4 \%$. Weak results in the car sales in 2004 were only a natural compensation for an extraordinary boom in 2003. Retail trade without an automotive segment showed a growth of $2.9 \%$ in 2004 . This was a notable slowdown from a year earlier, too (in 2003 the growth of $4 \%$ was registered). In this segment, the impact of slowdown in real wages was most pronounced.

Two changes in the Value Added Tax (in January and May 2004) brought a temporary speed-up of CPI inflation which culminated in October 2004 (yearly CPI at $3.5 \%$ ). Thereafter, inflation started to subdue. Yearly CPI inflation at the end of 2004 was $2.8 \%$, Till the end of March 2005, CPI inflation decreased further, reaching the level of $1.5 \%$. That meant that inflation fell under the CNB target corridor, and was more than half percentage point below eurozone inflation.

Producer prices started to rise sharply as of the second quarter of 2004: in March, the yearly index was still $2.1 \%$, in July it reached $7.3 \%$. The reason was the price increase of metals, steel products and oil products. Rising oil prices on the world market pushed prices of oil products up. Metals and steel prices were pushed up by a record demand in countries of Southeast Asia, and mainly in China and India. Producer prices in the CR reached their peak in October 2004 (increase by $8.6 \%$ ), then PPI inflation started to slow down again. Later on, in the course of five months, the year-over-year PPI declined to $6.4 \%$ in March 2005.

In 2004, fast pass-through of high raw material- and metal prices into prices of final investment goods, and, mainly, of consumer goods was prevented by strong competition. Also, Czech producers of steel products rapidly increased their exports, so that part of inflation was "exported" to other countries. However, the spillover effect was only temporarily dampened.

Since September 2004, the Czech currency again started to appreciate toward the euro. Some good macroeconomic figures (GDP growth, falling inflation, low interest rates, and strong export growth) together with the psychological effect of EU entry, had more impact than some other indicators that were negative - deficits of public finance and high (as well as persistent) unemployment. Appreciation of CZK against the dollar was even faster. That appreciation was able, in the recent two quarters, partly to neutralize the sizable increase of oil prices and prices of other raw materials (namely, metals) on the world markets.

Czech National Bank cut the basic repo rate twice during the first quarter of 2005 (at the end of January and at the end of March) - each time by 25 basis points. After three quarters, CNB basic rate has thus returned to $2 \%$, reaching the same level as the ECB basic rate. Cuts in the repo rate have not influenced the exchange rate - the koruna did not react by a weakening.

In 2004, the unemployment rate figures have been affected by the change of methodology. Ministry of Labour and Social Affairs changed the methodology of labour market data as of July 2004, in accordance with the ILO and Eurostat practice. Regarding this change, both the number of unemployed and the unemployment rate are lower under the new methodology (approximately by one percentage point).

First months of 2004 registered continuing deterioration on the labour market. In February 2004, the unemployment rate amounted to its historically highest level of $10.9 \%$ (in old methodology). The rate of unemployment stood at $9.2 \%$ according to the new methodology and at 10.1 according to the old one, in July 2004 . Second half of the year indicated stabilization of the situation. At the end of 2004, the unemployment rate reached $9.5 \%$ according to the new methodology and $10.3 \%$ in the old one. In 2004, the unemployment rate thus ended on exactly the same level as a year before. First months of 2005 show first signs of improvement. 


\section{Outlook for 2005}

We expect than in 2005, the Czech economy will grow by roughly the same pace as in 2004. The GDP growth will reach approximately $4 \%$. Contrary to 2004, the growth will be more balanced: consumer demand will slightly recover while investment demand will probably register a slowdown. The positive impact of external sector will be even more visible. Consumer demand will recover to $3 \%$ growth due to higher increase of real wages as a consequence of declining inflation. Fixed capital investment will grow by around $6 \%$. The growth above $4 \%$ seems rather unrealistic, having in mind the rather poor performance of euro zone's countries in 2005.

Two major risks remain: first, the surge of oil prices above 75 USD per barrel could cut the growth rate of the Czech economy by 0.2 to 0.4 percentage points. Second, the deceleration of the German economy to or under $1 \%$ could hinder the Czech exports (Germany accounts for one third of Czech exports) and would adversely influence the economic dynamics.

Trade balance will continue in improvement in 2005 - foreign trade figures from the first months of 2005 seem quite favourable for the trade balance prospects. Fundamental factors of improvement will be supported by ongoing activities of export oriented industrial companies under foreign control and new capacities in the car industry. On the other hand, the incomes balance will further deteriorate due to increasing reinvestments of profits and payments of dividends. The current account deficit will thus amount approximately to CZK 120 bill. in 2004 (USD 5.5 bill.). Under the assumption of approximately $4 \%$ growth of GDP, the ratio of the current account deficit to GDP would improve to $4.5 \%$.

Growth in industry will continue in 2005, although at a slightly lower pace than in 2004 - as indicated by the figures from the first months of the year. For 2005, we expect the growth of industrial output around 5-6\%. However, an economic slowdown in euro zone and high prices of oil combined with strengthening USD represent a risky factor which could somewhat cut this quite optimistic forecast.

Construction has potential for growth due to overall strong economic activity, continuing investments in infrastructure and investment projects of foreign investors. Also, growth of new construction permits and hiring of new workers has been giving some reasons for optimism. Spring months should register recovery of housing construction, however, there have already appeared signs of saturation on the markets with flats. Therefore, the double-digit growth rates will be rather an exception than a rule, in 2005 - the dynamics will be more close to the trajectory from the second half of 2004. In 2005, growth in construction will amount to approximately $3 \%$.

Low inflation and continuing fast growth of nominal incomes combined with increasing use of consumer credits have been giving space for improvement for 2005. Czech households will continue to keep their propensity to spend at a relatively high level. We expect that the growth of retail sales in 2005 will be around (or slightly above) $3 \%$.

In the second half of 2005, the fall of prices observable since January will continue. However, the second half of 2005 will again bring increasing consumer prices, due to price deregulation, and to high prices of oil. With a delay of several quarters, also the influence of rising producer prices (of second half of 2004 and start of 2005) will be felt. We expect CPI inflation at the end of 2005 about $2.0 \%$, average inflation about $1.5 \%$.

In 2005, prices of some raw materials and metals have started to decrease moderately, so that the peak of their growth is probably behind us. However, due to continuing high demand, and instability in some oil-producing countries, the price of oil will remain above the $55 \mathrm{USD} /$ barrel level for a longer time. We therefore ex- 
pect the producer price inflation to be around $2.0 \%$ in the Czech Republic at the end of 2005.

Exchange rate against the euro will move within the interval of $29.50-30.50$ CZK/EUR. External shocks excluded, Czech currency could temporarily weaken at the end of second quarter of 2005 (due to profit repatriation by foreign investors), in the same extent as last year (0.3 to $0.4 \mathrm{CZK})$. Thereafter, it would return to the longer-term trend of $3-4 \%$ yearly appreciation.

We expect 2005 to be a year of low interest rates. Interest rates in the Czech Republic will remain under the euro zone level - with high probability - until the end of the year. Appreciating currency, relatively good growth and exports figures, and low inflation will support the "wait and see" stance. Possible adjustment in CNB interest rates can thus rather be expected at the beginning of 2006 , depending on a rate change by the ECB.

First signs of improvement on the labour market have been registered in the beginning of 2005, as a consequence of strong economic activity. The consolidation of the situation in industry seems to be helpful for the overall employment conditions. Due to demographic developments, the new wave of graduates entering the labour market should not be very strong, in 2005. The rate of unemployment will be slightly under $9 \%$, at the end of 2005 .

\section{External Environment}

\section{1 Outlook of the World Economy}

World economic outlook is relatively positive in the first third of 2005. After the highest rate of growth for the last almost 30 years (4.9\%) in 2004, growth above $4 \%$ can again be expected for the current year (see Table 2). And, like in 2004, world growth will again be driven by the United States, by Southeast Asia (mainly, China and India), and by Latin America. The growth rates of the euro zone and Japan will again remain 2.5 - 3 times lower than in the U.S., and even worse compared to China or India.

Table 2

World Economy in 2003 - 2005 (GDP growth in \%, constant prices)

\begin{tabular}{|l|c|c|c|}
\hline & 2003 & 2004 & 2005 \\
\hline World & 3.6 & 4.9 & 4.1 \\
\hline USA & 3.0 & 4.4 & 3.8 \\
\hline Eurozone & 0.5 & 1.8 & 1.3 \\
\hline - France & 0.5 & 2.3 & 2.0 \\
\hline - Germany & -0.1 & 1.6 & 1.0 \\
\hline Japan & 2.7 & 2.6 & 1.5 \\
\hline Asia (excl. Japan) & 7.1 & 7.9 & 7.0 \\
\hline Latin America & 1.3 & 6.1 & 4.5 \\
\hline
\end{tabular}

Source: Societé Générale, Komerční banka.

Relatively robust growth of the world economy so far is not accompanied by any significant increase in inflation. Price increases of oil and other raw materials (na- 
mely metals), which always accompany a growing demand, are dampened by the strong competition between the main world market players - China, India, and the Central- and East-European new EU members. Competition is reinforced also by the abundance of free capacity in advanced OECD countries.

Even the strong price increase of oil, with prices dwelling around USD 55 per barrel, so far has shown no retarding effect on the world economy. First, a good part of the nominal price increase was compensated by the weakening dollar, mainly in relation to the euro. Second, in real terms, the USD 55 per barrel is equal to $60 \%$ of the 1982 price. Moreover, while in 1982 oil represented about $8 \%$ of the world GDP, nowadays it is less than $2 \%$. So, the impact of oil prices on world economic growth is now less pronounced.

Critical is the question of robustness of world economic growth, in the light of the twin deficits (budget and current account) in the U.S., and of the wide gap between the sluggishness of euro zone and Japan, on the one hand, and the strong dynamics of the USA and Asia (excluding Japan) on the other. To lower the risks, and keep the volatility of world growth in limits, the following policies would be desirable:

- The euro zone and Japan should pursue economic policies promoting growth based on domestic demand;

- The U.S. should adopt fiscal corrective measures, cut the federal budget deficit, and reduce the danger of a steep fall of the dollar;

- China and other Southeast-Asian countries should gradually appreciate their currencies, to prevent an overheating of their economies.

To what extent such a positive scenario can be realized - that is the main question, and challenge, for the current year, and for 2006.

\section{2 Central-European New Member States}

For the four Central-European countries, 2004 - the year of their EU entry - was characterized by a speed-up of economic growth, resulting in growth figures up to twice higher than in the euro zone. All four countries (CE 4) showed a fast increase of exports, the Czech Republic being the leader. The Czech Republic and Slovakia also were receiving a continuing inflow of foreign investment. Currencies of all four countries started to appreciate since the second half of 2004 , contributing - in spite of a sizable price increase of imported materials - to a decline in inflation.

Table 3

GDP Growth in CE 4 New Member States (in \%, constant prices)

\begin{tabular}{|l|c|c|c|}
\hline & 2003 & 2004 & $2005 f$ \\
\hline Poland & 3.8 & 5.3 & 4.6 \\
\hline Hungary & 3.0 & 4.0 & 4.0 \\
\hline Slovakia & 4.5 & 5.5 & 5.0 \\
\hline Czech Republic & 3.7 & 4.0 & 4.0 \\
\hline
\end{tabular}

Source: National Statistical Offices, Komerční banka.

Lower inflation resulted in relatively bold cuts of interest rates in Hungary and Poland, since the start of 2005. In the Czech Republic, after the last interest rate cut at the end of March 2005, the repo rate is again at the level of the ECB basic rate, with 3-month Pribor at, or even below, the 3M Euribor. Convergence of inte- 
rest rates between the CE 4 new member states, and the euro zone, has been an important feature of the first year of their EU membership.

Slovakia has been the leader in fiscal consolidation, with substantial reforms of the tax system, the pension system, and the system of health-care undertaken in 2003 and 2004. The outlook of public finance makes Slovak adoption of the euro very probable in 2009.

In Poland, weak position of the government practically stopped all reforms in 2002. A turn can only be expected after the September 2005 parliamentary election - that is, in effect, no sooner than in 2006. The same is true of Hungary which now shows the highest deficits both of public finance and of the current account of balance of payments.

One, however, has to note than both Poland and Hungary have declared a firm intention to reform in 2006 and 2007 the tax system fundamentally, adopting the flat tax, to follow the inspiring Slovak example.

\section{Gross Domestic Product}

In 2004, the Czech GDP increased by $4.4 \%$, which represents a slight acceleration against 2003 (3.2\%). As for demand factors, the investment demand registered a strong acceleration to $9.1 \%$, - the highest growth since 1996 (which is the last year of comparable data series so far). Gradual weakening of consumer demand from $2.8 \%$ in the first quarter to $5 \%$ in the last one resulted in much weaker fullyear growth of consumer demand. Consumption of households thus increased by $2.0 \%$ in 2004 , down from $4.9 \%$, registered in 2003. Weakening of consumer demand was caused in particular by slower growth of real wages - the full-year growth of $3.7 \%$ has been the lowest result within previous four years. Government consumption fell by $2 \%$ due to increased prudency in public finance.

Figure 1

GDP: Consumer and Investment Demand (growth rates in \%)

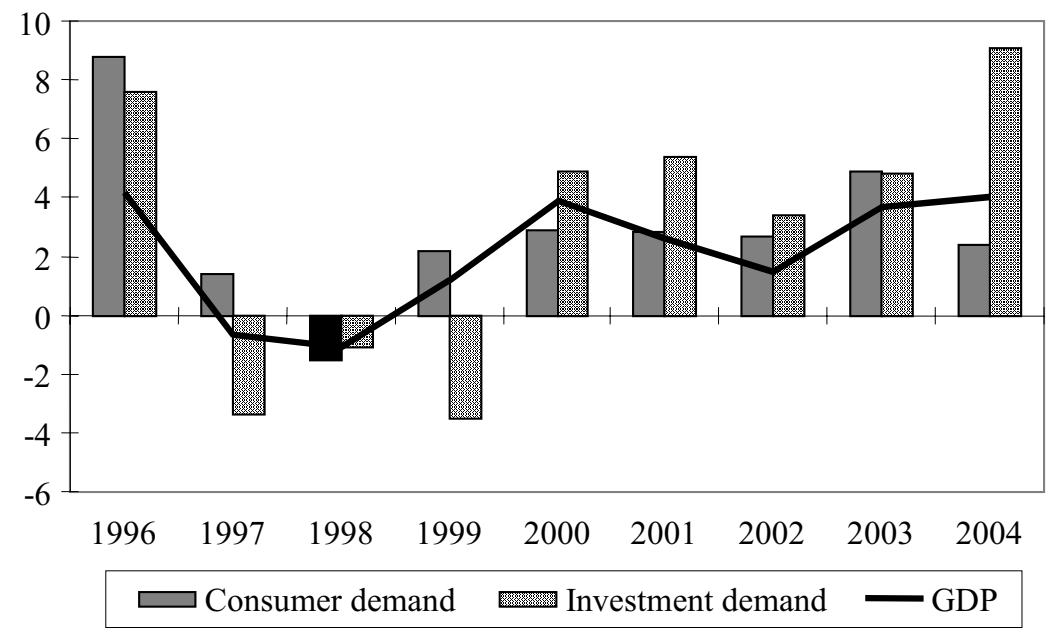

Source: Czech Statistical Office. 
The absolute increase of GDP (in constant prices) amounted to CZK 113.5 bill. - see Table 4. This table confirms clearly the position of investment demand as major growth factor and illustrates also the improving impact of trade with goods. Net exports of goods accounted for the increase in GDP amounting to CZK 43.3 bill., which was a visible improvement against 2003. At the same time, the impact of net foreign trade with goods to overall GDP growth was more significant than the impact of consumption of households. Trade with services registered a neutral impact on GDP. It is clear that the EU entry was an important factor supporting Czech exports of goods, in the second half of the year. The Czech economy has thus been gradually becoming an export-driven one.

Table 4

GDP Growth: Absolute Increases (in CZK bill.)

\begin{tabular}{|l|c|c|}
\hline & 2003 & 2004 \\
\hline GDP & 89.7 & 113.5 \\
\hline Consumption of households & 60.0 & 26.5 \\
\hline Consumption of government & 23.3 & -12.3 \\
\hline Gross capital formation & 31.2 & 51.8 \\
\hline Net exports of goods & 5.0 & 43.3 \\
\hline Net exports of services & -8.5 & 0.9 \\
\hline
\end{tabular}

Source: Czech Statistical Office.

Note: This table presents only the most important demand items, some marginal items have been omitted (change in inventories, net acquisition of valuables and NPISH), therefore the sum of individual absolute increases does not correspond to overall GDP.

As for individual sectors, manufacturing industry continued to be the main driving force of GDP. In 2004, GDP in manufacturing industry rose by $6.7 \%$, which was

Figure 2

GDP: Growth in Individual Industries (growth rates in \%)

$$
\text { Construction }
$$

Hotels and restaurants

Real estate

Electricity, gas and water

Trade

Transport and communications

GDP

Manufacturing industry

Mining and quarrying

Finance and insurance

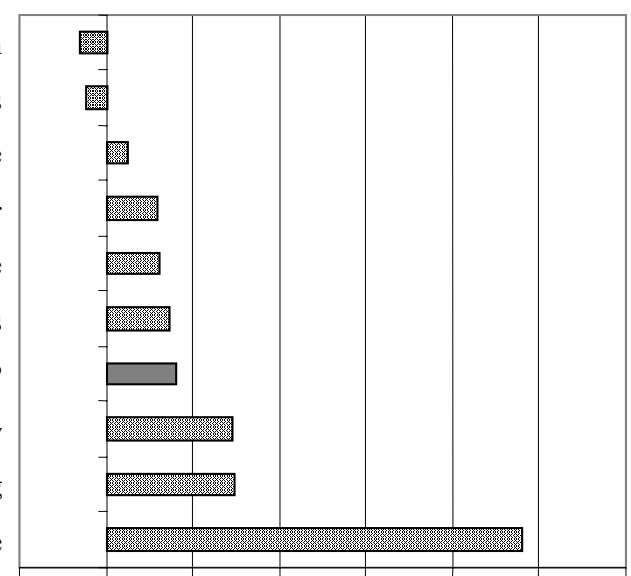

$\begin{array}{llllllll}-5 & 0 & 5 & 10 & 15 & 20 & 25 & 30\end{array}$

Source: Czech Statistical Office. 
slightly lower growth in comparison with growth of $8.3 \%$ in 2003. Manufacturing industry accounted for $37 \%$ of GDP. GDP in services rose by $2.5 \%$. The share of services in total GDP amounted to $60 \%$. The growth of GDP in services was strongly differentiated. The highest growth registered finances and insurance with growth of GDP amounting to $33.7 \%$. Wholesale and retail trade witnessed quite solid growth of $7.5 \%$.

\section{External Balance}

In 2004, Czech balance of payments ended in a surplus. Current account deficit amounted to CZK 143.3 bill., down from CZK 160.6 bill. in 2003. The decline in current account deficit was caused predominantly by improvement of trade balance. Current account deficit thus reached $5.2 \%$ of GDP, which was an improvement against $6.3 \%$ in 2003. Financial account registered a surplus of CZK 180.9 bill., up from 157.1 bill., a year before. Financial account revealed a recovery of FDI inflows, increased purchases of Czech portfolio investments by foreign investors and a small net inflow of other investments.

Table 5

Balance of Payments (CZK bill.)

\begin{tabular}{|l|r|r|c|}
\hline & 2003 & 2004 & $2005 \mathrm{~F}$ \\
\hline Current account & -160.6 & -143.3 & -120 \\
\hline O.w.: Foreign trade & -69.8 & -22.3 & 20 \\
\hline Balance of services & 13.2 & 12.5 & 15 \\
\hline Balance of incomes & -119.9 & -139.5 & -160 \\
\hline Transfers & 15.8 & 6.1 & 10 \\
\hline Capital account & -0.1 & -14.0 & -15 \\
\hline Financial account & 157.1 & 180.9 & 210 \\
\hline o.w.: Direct investments & 53.5 & 100.7 & 180 \\
\hline Portfolio investments & -35.7 & 62.2 & n.a. \\
\hline Financial derivatives & 3.9 & -1.5 & n.a. \\
\hline Long-term capital & 27.5 & 50.3 & n.a. \\
\hline Short-term capital & 107.9 & -30.7 & n.a. \\
\hline
\end{tabular}

Source: Czech National Bank, forecast KB.

\section{1 Current Account}

\section{Trade with Goods}

In 2004 , the exports rose by $23.8 \%$, the imports increased by $19.2 \%$. The fullyear trade deficit amounted to CZK 20.6 bill. - a strong improvement of CZK 49.2 bill. in comparison with 2003. 2004 result was the best one since 1994. At the same time, 2004 may be depicted as the year of significant turnover in foreign trade, which has been only gradually improving in the course of previous five years. 
The EU entry was an important reason behind the improvement of trade balance. The foreign trade significantly accelerated after the EU accession. The exports increased by $16.3 \%$, January to April 2004, accelerating to $27.4 \%$, May to December. The acceleration of exports thus amounted to more than 10 percentage points, after the EU accession. The increase of imports was less pronounced: imports increased by $20.8 \%$, May to December, after growth of $15.8 \%$, January to April 2004. The EU entry opened new chances to the exporters; especially small and mediumsized companies could fully use the advantage of the Single EU Market. It seems probable that not only the administrative barriers but also the psychological ones were eliminated.

A positive impact of foreign trade prices on Czech trade balance was quite notable. The import prices rose by $1.6 \%$ on average, the export ones rose by $3.7 \%$. Terms of trade thus improved by $2.1 \%$. If the prices remained at the average level of 2003, the trade balance would have deteriorated by CZK 40 bill. The impact of record high world prices of some commodities was differentiated as for individual commodity groups, therefore the development of foreign trade prices were strongly differentiated, too. It is important that the terms of trade improved in the most important commodity group - machinery and transport equipment - which indicates increasing competitiveness of these products on foreign markets.

Table 6

Import Prices, Export Prices, Terms of Trade

\begin{tabular}{|l|c|c|c|}
\hline & $\begin{array}{c}\text { Import prices } \\
\text { y/y indices }\end{array}$ & $\begin{array}{c}\text { Export prices } \\
\text { y/y indices }\end{array}$ & Terms of trade \\
\hline Total & 101.6 & 103.7 & 2.1 \\
\hline Food & 102.5 & 103.5 & 1.0 \\
\hline Tobacco and beverages & 105.1 & 90.1 & -14.3 \\
\hline Raw materials (excl. fuels) & 109.1 & 102.1 & -6.4 \\
\hline Fuels & 106.5 & 120.1 & 12.8 \\
\hline Oils, fats and waxes & 102.8 & 101.4 & -1.4 \\
\hline Chemicals & 101.7 & 107.3 & 5.5 \\
\hline Semi-manufactured goods & 104.3 & 108.2 & 3.7 \\
\hline Machinery, transport eq. & 98.6 & 100.3 & 1.7 \\
\hline Manufactured articles & 99.4 & 100.2 & 0.8 \\
\hline
\end{tabular}

Source: Czech Statistical Office.

The most important segment of Czech foreign trade continued to be machinery and cars which accounted for more than half of the exports. Trade surplus in the trade with machinery almost doubled in comparison with previous year, amounting to CZK 140 bill. Also the trade with semi-manufactured goods produced a surplus of CZK 26 bill. The trade deficit in 2004 was concentrated to chemicals (CZK -86 bill.) and raw materials (CZK - 72 bill.).

In 2004, the growth of exports to the EU was above average amounting to $23.3 \%$. The trade balance with the EU 25 reached a surplus of CZK 219.3 bill. in 2004. The surplus with euro zone amounted to CZK 123 bill., major trade partner - Germany - 
accounted for CZK 75 bill. On the other hand, the highest deficits were produced in the trade with China (CZK 81 bill.), Russia (CZK 50 bill.) and Japan (CZK 47 bill.)

\section{Balance of Incomes and Services}

The deficit of the income balance further increased to CZK 139.5 bill. Balance of incomes has been the main source of current income deficit since 2002, which was the first year when the deficit of incomes had exceeded the trade deficit (see Table 7). Since then, trade balance has continued to improve and balance of incomes has been deteriorating. In 2004, the negative impact of the trade balance on current account was only marginal and the balance of incomes accounted for $85 \%$ of the negative items.

Repatriation of profits and payments of dividends have been the main factors of deficit of the incomes balance. This is the adverse side of massive inflow of foreign direct investments from the past decade. In comparison with 2000 , the revenue of the incomes balance almost did not change but the expenditure rose by more than

Table 7

Current Account: Trade Balance, Balance of Services (CZK bill.)

\begin{tabular}{|l|r|r|r|r|r|}
\hline & \multicolumn{1}{|c|}{2000} & \multicolumn{1}{|c|}{2001} & \multicolumn{1}{c|}{2002} & \multicolumn{1}{c|}{2003} & \multicolumn{1}{c|}{2004} \\
\hline Current account & -104.9 & -124.5 & -136.4 & -160.6 & -143.3 \\
\hline Current account (\% of GDP) & -4.9 & -5.4 & -5.6 & -6.3 & -5.2 \\
\hline Trade balance & -120.8 & -116.7 & -71.3 & -69.8 & -22.3 \\
\hline Balance of incomes & -53.0 & -83.5 & -116.6 & -119.9 & -139.5 \\
\hline
\end{tabular}

Source: Czech National Bank.

Figure 3

Balance of Incomes (CZK bill.)

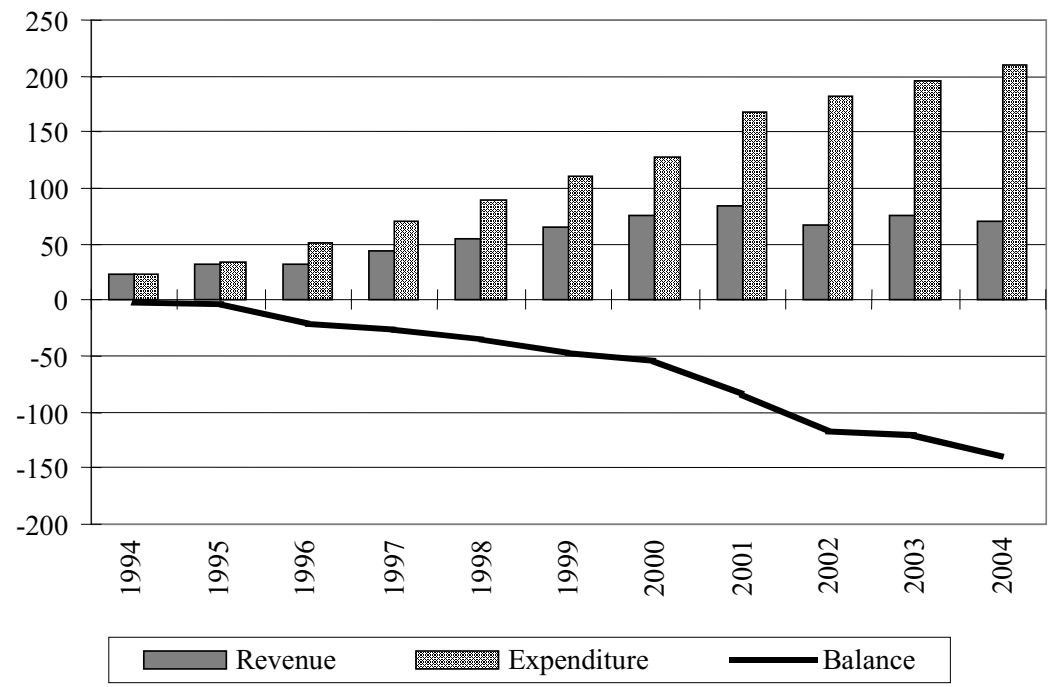

Source: Czech National Bank. 
$60 \%$. The Czech Republic has thus confirmed the experience of many economies with strong FDI inflows: the positive impact of FDI on exports and trade balance is accompanied by the negative impact on the balance of incomes.

Balance of services performed roughly in the same way like a year before. The net surplus negligibly declined to CZK 12.4 bill., which was a contraction of CZK 0.8 bill. against 2003. The growth of expenditure was slightly higher than increase of incomes (15\% and $13 \%$, respectively). Trade with services which looked as a quite promising in the nineties, thus became a marginal contributor to the revenue of the current account. At the same time, trade with services has been affecting adversely also the GDP growth in the recent years.

\section{2 Financial Account}

The surplus of the financial account amounted to CZK 180.9 bill. in 2004, slightly above the surplus of CZK 157.1 bill. in 2003. The inflow of foreign direct investments slightly recovered in 2004, net FDI amounting to CZK 100.7 bill.(up from CZK 53.5 bill. in 2003). The cumulative inflow of FDI in $1993-2004$ thus amounted to almost CZK 1,300 bill. Almost one half of the FDI inflow was oriented to the sector of services, with most significant inflow to the banking sector. A very strong inflow of FDI registered retail trade, due to activities of international retail chains. More than $40 \%$ of FDI came to Czech manufacturing, with the highest volume of FDI in the automotive industry. Also, food industry, metal industry, manufacture of coke and refined oil products registered total volume of FDI exceeding CZK 50 bill. (see Table 8).

Table 8

FDI Inflow (1993 - 2004)

\begin{tabular}{|l|c|c|}
\hline & CZK bill. & Share in \% \\
\hline FDI - total & $1,276.5$ & 100 \\
\hline Manufacturing industry & 541.8 & 42.4 \\
\hline - automotive industry & 118.7 & 9.3 \\
\hline Services & 602.0 & 47.1 \\
\hline - trade & 162.6 & 12.7 \\
\hline - banking sector & 208.2 & 16.3 \\
\hline
\end{tabular}

Source: Czech National Bank.

Major part of FDI - almost $90 \%$ - came from the Western Europe. The Netherlands accounting for one third of FDI inflow was the major investor, followed by Germany (20\%) and Austria (12\%).

Portfolio investments with net inflow of CZK 62.2 bill. showed much better result than a year before. The activities of foreign investors were concentrated to debt securities - their purchases amounted to 103.7 bill. in 2004 up from CZK 18 bill. in 2003. The purchases of foreign portfolio investments made by Czech investors amounted to CZK 61 bill., which was a small contraction against previous year (CZK 83.9 bill.). 
Figure 4

FDI Inflow (1993 - 2004)

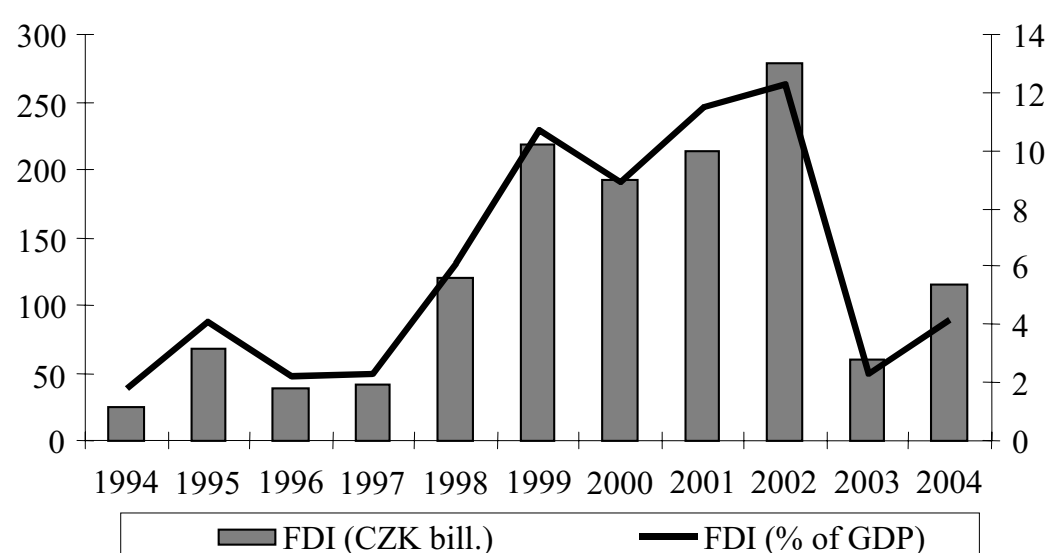

Source: Czech National Bank.

Net inflow of other investments reached CZK 19.6 bill., which was significantly lower figure than a year before (CZK 135.5 bill). The main reason for this difference was a net outflow of short-term capital amounting to CZK 30.7 bill. On the other hand, long-term capital continued to inflow due to increasing loans of domestic companies and government activities. Net inflow of long-term capital thus reached CZK 50.3 bill.

\section{Outlook}

Trade balance will continue in improvement in 2005 - foreign trade figures from the first months of 2005 seem quite favourable for the trade balance prospects. Fundamental factors of improvement will be supported by ongoing activities of export oriented industrial companies under foreign control and new capacities in the car industry (the trade surplus produced by TPCA is estimated at CZK 20 bill.). We expect a full-year trade surplus of CZK 35 bill. for 2005.

Balance of services will not probably show any significant change and will register a small surplus. The incomes balance is expected to deteriorate further due to increasing reinvestments of profits and payments of dividends. This is the price for massive FDI inflows from the previous period. It is rather paradoxical that FDI were on the one hand the major factor of consolidation of the trade balance, but on the other one, have become the main reason behind still high current account deficit due to reinvestments and repatriations of profits. The current account deficit will thus amount approximately to CZK 120 bill. in 2004 (USD 5.5 bill.). Under the assumption of approximately $4 \%$ growth of GDP, the ratio of the current account deficit on GDP would further decline to $4.5 \%$. 


\section{Domestic Demand}

\section{1 Industry}

Witnessing robust growth, Czech industry performed well in 2004. The growth of industrial output accelerated to $9.9 \%$ up from $5.8 \%$ in 2003 . Industrial sales registered almost the same growth rate as output $-9.8 \%$. A small difference between growth of output and sales has been indicating balanced growth in the Czech industry. The growth in industry did not register any significant fluctuations in the course of the year.

Growth in industry in 2004 was concentrated to manufacturing industries, which rose by $10.8 \%$. Raw material industries contracted by $0.9 \%$. Industrial output was driven in particular by three industries: metal industry with growth of $23 \%$, production of electrical appliances (15.3\%) and car industry $(14.3 \%)$. Strong growth in metal industry was supported in particular by strong demand in Asia (predominantly by the Chinese one).

In 2004, industry continued to be driven in particular by the exports, especially by the export-oriented companies under foreign control. The direct export sales rose by $17.0 \%, y / y$, their share on total industrial sales reaching $49.1 \%$. Direct export sales accelerated after the EU accession: May - December 2004, the growth of direct export sales amounted to $19 \%$, after a growth of $12.9 \%$, January to April. Electro-technical industry reported the highest growth of direct export sales $(63.2 \%)$, followed by metal industry $(26.1 \%)$ and chemistry $(26 \%)$.

Both total sales and direct export sales continued to grow more rapidly in the segment of foreign-controlled companies - see Table 9. In 2004, 1,842 companies under foreign control were registered in the Czech industry, with employment amounting to 425.6 thousands people. The share of foreign-controlled companies seems to stabilise, accounting for $52.8 \%$ of industrial sales. The companies under foreign control are primarily export-oriented - direct export sales accounted for $72.8 \%$ of their total sales. Foreign-controlled companies continue to be the major driving force of the Czech industrial output and exports.

Table 9

Growth of Sales in 2004 (growth rates in \%)

\begin{tabular}{|l|c|c|c|c|}
\hline & \multicolumn{2}{|c|}{ All industrial companies } & \multicolumn{2}{c|}{ Companies under foreign control } \\
\cline { 2 - 5 } & 2003 & 2004 & 2003 & 2004 \\
\hline Total industrial sales & 5.4 & 9.8 & 7.1 & 14.8 \\
\hline Direct export sales & 8.8 & 17.0 & 10.3 & 20.0 \\
\hline
\end{tabular}

Source: Czech Statistical Office.

The growth of productivity continued to outpace the growth of real wages: in 2004 , productivity rose by $10.4 \%$, real wage increased by $4.0 \%$. The decline of unit labour costs enables to keep the competitiveness of Czech industrial exporters on foreign markets. This is one of the reasons behind solid growth in industry even under the appreciating CZK.

Recovery of employment in some industries has been one of the good news in the Czech industry. Major part of restructuring has been over, which attenuated also overall labour market pressures. Total industrial employment declined by $0.5 \%$ in 2004, which was a decline of only 6 thousand people. However, the employment 
continued to decline merely in mining and quarrying (-4.8\%), while manufacturing industries registered stagnation. As of June 2004, the employment in manufacturing has registered a moderate growth. The best performing industries hired new employees in the course of the whole year. Therefore, in 2004, employment rose in electro-technical industry, car industry and metal industry (by $5.4 \%, 3 \%$ and $0.8 \%$, respectively).

\section{2 Construction}

The full year growth of construction output amounted to $9.7 \%$, in 2004, which has been the best result since 1993. However, the growth was concentrated to the first four months of the year, when extremely strong activity from the second half of 2003 continued due to expected change of VAT. May to December 2004, the construction output rose by merely $2.6 \%$, after a growth of $27 \%$, January to April 2004 .

As of May 2005, construction works (with the exception of housing where the reduced rate of $5 \%$ will be effective until the end of 2007) have been burdened by $19 \%$ standard rate of VAT instead of previous rate of $5 \%$. This change was postponed from previously announced date of January 2005 - therefore the boom in construction took place as early as in the second half of 2003. Change of VAT promoted the investors to finish as much works as possible until April 2004. The growth in April 2004 - which was the last month with the possibility of invoicing construction works under the reduced $5 \%$ VAT rate - was an extraordinary and unrepeatable result of $62.4 \%$. Large amounts of construction works were pre-invoiced.

Slowdown in construction observed since May was a natural compensation for extremely rapid growth from the first months of the year. The extremities caused by the VAT change have affected the figures on construction output until August 2004. From August till December 2004, construction followed an average growth path around 5-6\%, which can be also considered as mid-term potential. Quite optimistic assessment of the construction has been confirmed also by continuous hiring of new workers: in 2004 employment in construction increased by $3.4 \%$.

Figure 5

Construction Output (growth rates in \%)

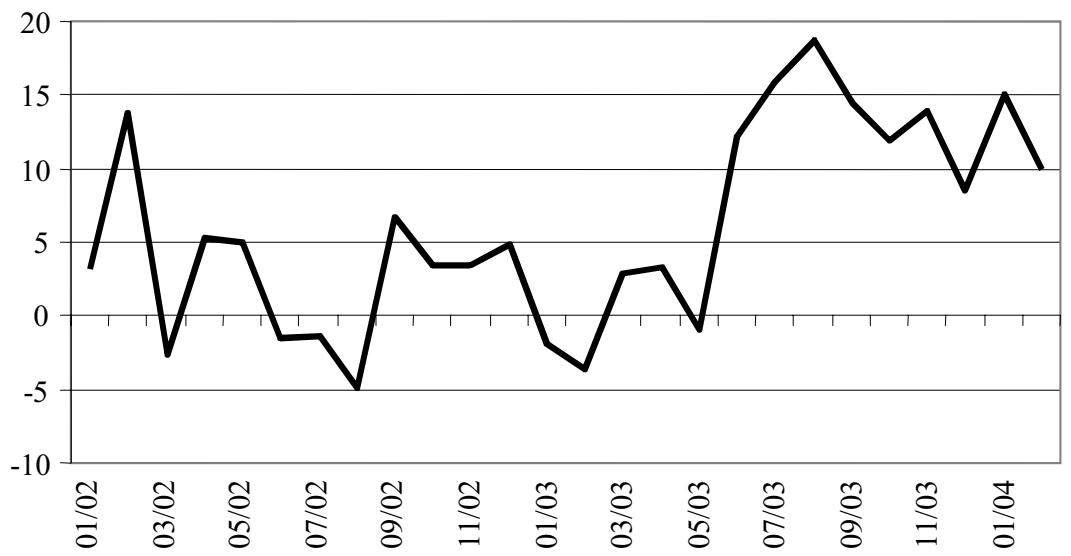

Source: Czech Statistical Office. 
Growth in construction was driven especially by large building and civil engineering projects (highways, railway corridors, Prague metro and tram lines, business, distribution and logistic centres). Similar to industry, activities of foreign investors had a positive impact, supporting in particular construction of business centres and assembly halls.

In European context, the share of housing in total construction output has still been quite low (12.6\%). In 2004, construction of 40 thousands new flats was permitted (39 thousands in 2003). In housing construction, mortgage market has been playing a key role. Number of mortgages continued to grow (30\%), however at a slower pace than in 2003 (50\%). Similarly, their value increased by $43 \%$ in 2004, after a growth of $57 \%$ in 2003.

Figure 6

Newly Permitted Flats (in thousands)

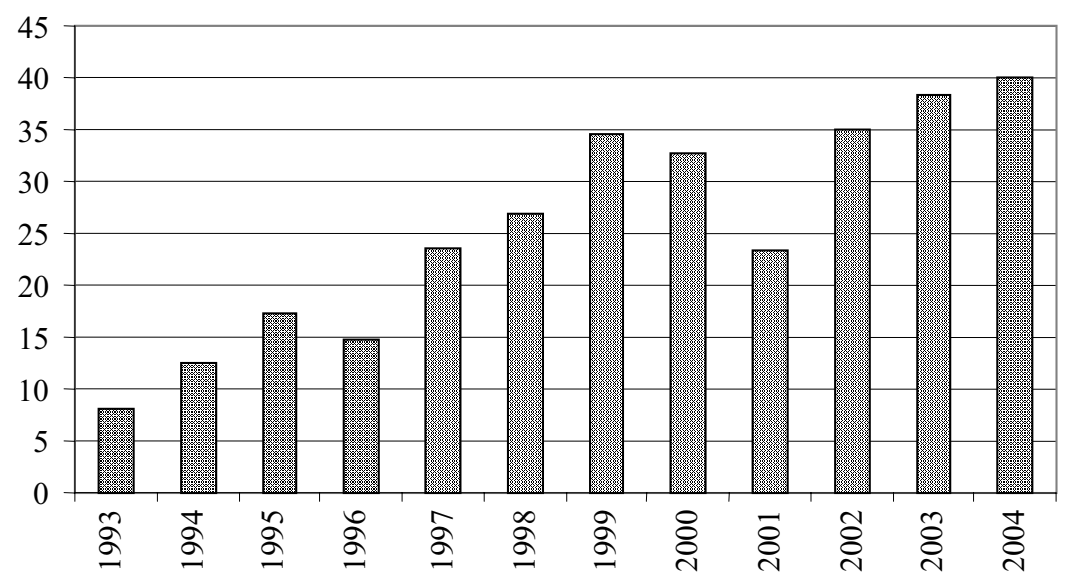

Source: Czech Statistical Office.

\section{3 Retail Trade}

In 2004 , retail sales registered a notable slowdown to $2.5 \%$, after a robust $5 \%$ growth in 2003. At the same time, this has been the lowest figure since 1998. Along with slowdown in retail trade, also overall consumer demand weakened in the course of 2004 - see Figure 7. However, retail trade witnessed signs of recovery in the last quarter of the year, when the growth of $4.1 \%$ was registered after growth rates amounting to $1.2 \%, 2.5 \%$ and $1.7 \%$, in the first, second and third quarters of the year.

The main reason behind weak retail trade results in 2004 was the automotive segment. Let us remind that automotive segment, which accounts for approximately one third of retail sales volume, registered a very rapid growth in June - September 2003. Therefore, weak results in the car sales in 2004 were only a natural compensation for this extraordinary boom. On average, automotive segment increased by $1.6 \%$ in 2004 which was a strong slowdown against 2003 (7.2\%), car sales increasing by $2.4 \%$ and fuel sales by $2.7 \%$. Car repairs declined by $2.7 \%$.

Retail trade without an automotive segment showed a growth of $2.9 \%$ in 2004 . This was a notable slowdown from a year earlier, too (in 2003 the growth of $4 \%$ was registered). In this segment, the impact of slowdown in real wages was most pro- 
Figure 7

Retail Sales and Consumer Demand (growth rates in \%)

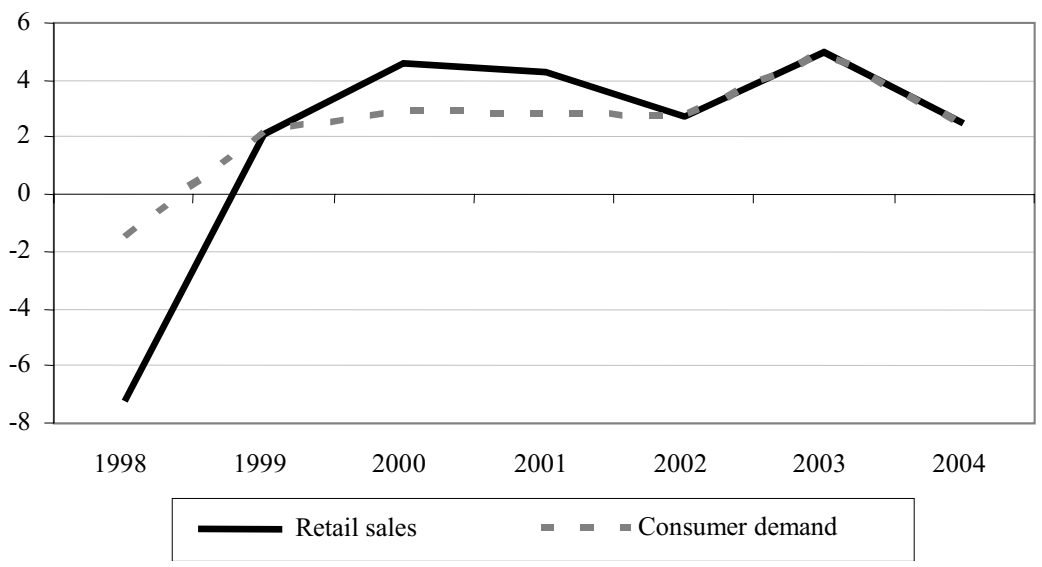

Source: Czech Statistical Office.

nounced. Sales of food increased by 2.4 down from $4.2 \%$ in 2003. Sales of nonfood consumer goods rose by $3.3 \%$, showing the lowest year over year slowdown (by 0.5 percentage points) of all segments. Non-food consumer goods is the segment where the supportive impact of consumer loans has been felt most strongly. The total volume of consumer loans granted to Czech households amounted to CZK 69.3 bill. at the end of 2004. This volume rose by CZK 8.3 bill. (13.6 \%) against yearend of 2003.

Figure 8

Retail Sales: Automotive Segment, Foods and Consumer Goods (growth rates in \%)

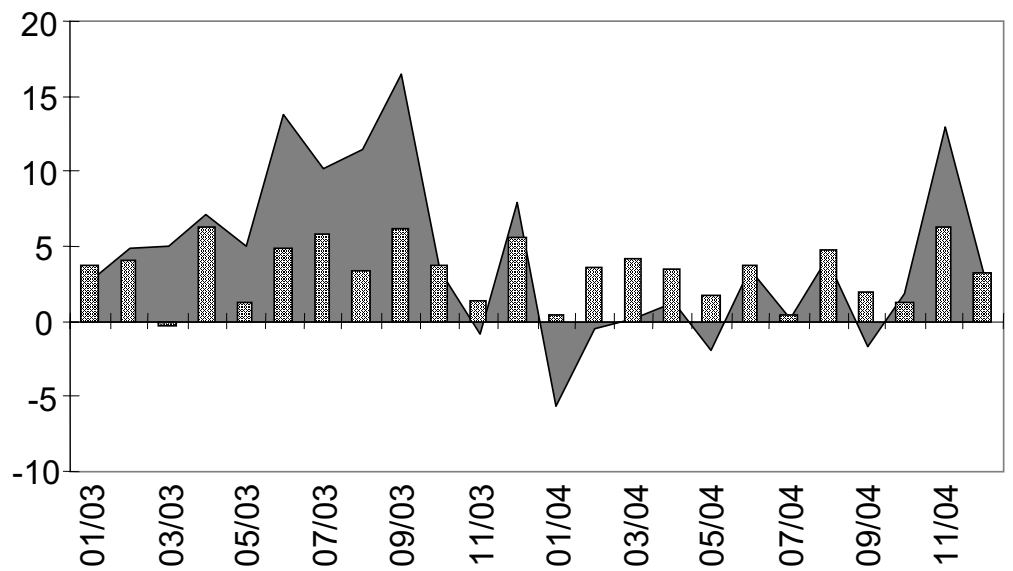

$\square$ Automotive segment

Goods and consumer goods

Source: Czech Statistical Office. 
Figure 9

Consumer Credits (2000 - 2004)

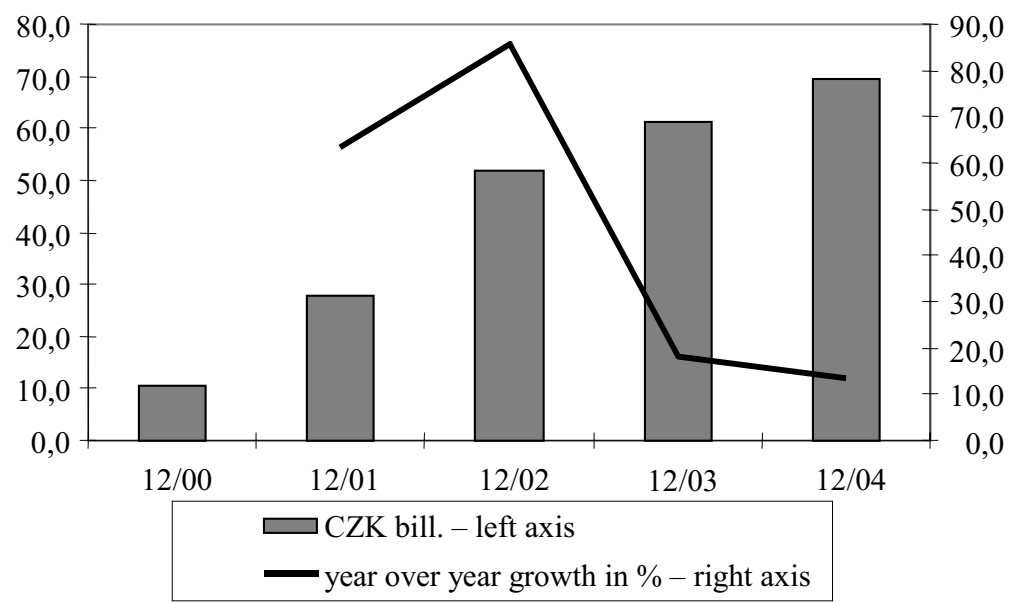

Source: Czech National Bank.

\section{Outlook}

Industry registered a slowdown in the beginning of 2005. It is obvious that the growth rates above $10 \%$ cannot be sustainable in the medium-term run. Also, the growth of new orders registered a notable slowdown. Growth in industry will therefore continue in 2005, although at a lower pace than in 2004. For 2005, we expect the growth of industrial output around 5-6\%. However, an economic slowdown in euro zone and high prices of oil combined with strengthening USD represent a risky factor which could somewhat cut this quite optimistic forecast.

Construction has potential for growth due to overall strong economic activity, continuing investments in infrastructure and projects of foreign investors. Also, growth of new construction permits and hiring of new workers has been giving some reasons for optimism. Spring months should register recovery of housing construction; however, there already have appeared signs of saturation on the markets with flats. Anyway, the double-digit growth rates will be rather an exception than a rule, in 2005 - the dynamics will be more close to the trajectory from the second half of 2004. In 2005, growth in construction will amount to approximately $3 \%$.

Low inflation and continuing fast growth of nominal incomes combined with increasing use of consumer credits have been giving some space for improvement for 2005. Czech households will continue to keep their propensity to spend at a relatively high level. We expect that the growth of retail sales in 2005 will be around (or slightly above) $3 \%$.

\section{Inflation}

\section{1 Consumer Prices}

Two changes in the Value Added Tax (in January and May 2004) brought a temporary speed-up of CPI inflation which culminated in October 2004 (yearly CPI index $3.5 \%$ ). Thereafter, inflation started to subdue. Yearly CPI inflation at the end of 
Figure 10

CPI and PPI (in \%, y/y)

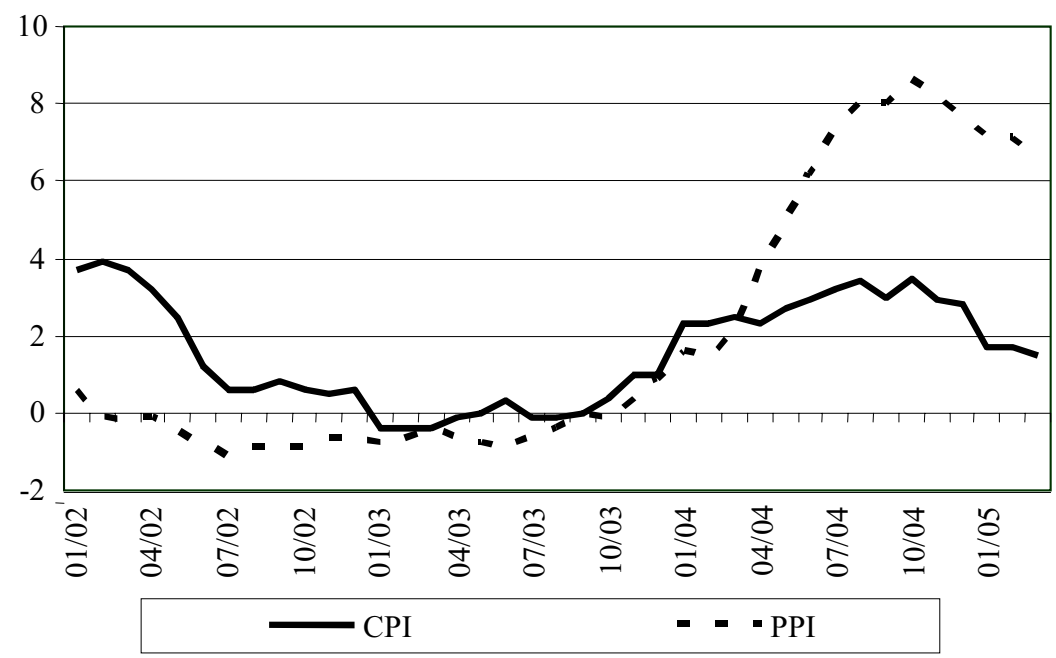

Source: Czech Statistical Office.

2004 was $2.8 \%$, caused mainly by price rises in communications (12.9\%), hotels and restaurants $(7.9 \%)$, education (5.4\%), and housing (4.4). Food prices rose by $0.9 \%$, transport prices by $1.4 \%$. Prices of clothing and shoes fell by $3.1 \%$. Till the end of March 2005, CPI inflation decreased further, reaching the level of $1.5 \%$. That meant that inflation fell under the CNB target corridor, and was more than half percentage point below euro zone inflation.

Table 10

CPI Inflation (Q3/2004 - Q1/2005, in \%, y/y)

\begin{tabular}{|c|c|c|c|c|c|c|c|c|}
\hline $7 / 2004$ & $8 / 2004$ & $9 / 2004$ & $10 / 2004$ & $11 / 2004$ & $12 / 2004$ & $1 / 2005$ & $2 / 2005$ & $3 / 2005$ \\
\hline 3.2 & 3.4 & 3.0 & 3.5 & 2.9 & 2.8 & 1.7 & 1.7 & 1.5 \\
\hline
\end{tabular}

Source: Czech Statistical Office.

Tax changes mainly influenced the prices of services. In 2004, service prices grew by $6.1 \%$, while goods prices only by $0.9 \%$. The same trend continues in 2005 . In addition to taxes, it is also caused by the fact that stronger competition in the goods markets keeps prices down - while in services, the more oligopolistic market structure provides room for larger price increases.

In the second quarter of 2005, the fall of prices observable since January will continue. However, the second half of 2005 will again bring increasing consumer prices, due to price deregulation, and to high prices of oil. With a delay of several quarters, also the influence of rising producer prices (of second half of 2004 and start of 2005) will be felt. We expect CPI inflation at the end of 2005 to be at about $2.0 \%$, average inflation about $1.5 \%$. 


\section{2 Producer Prices}

Producer prices started to rise sharply from the second quarter of 2004: in March, the yearly index was still $2.1 \%$, in July it reached $7.3 \%$ (See Table 11). The reason was the price increase of metals, steel products and oil products. Rising oil prices in the world market pushed prices of oil products up. Metals and steel prices were pushed up by a record demand in countries of Southeast Asia, and mainly in China and India. Producer prices in the CR reached their peak in October 2004 (increase by $8.6 \%$ ), than PPI inflation started to slow down again.

Table 11

PPI Inflation (Q3/2004 - Q1/2005, in \%, y/y)

\begin{tabular}{|c|c|c|c|c|c|c|c|r|}
\hline $7 / 2004$ & $8 / 2004$ & $9 / 2004$ & $10 / 2004$ & $11 / 2004$ & $12 / 2004$ & $1 / 2005$ & $2 / 2005$ & $3 / 2005$ \\
\hline 7.3 & 8.1 & 8.0 & 8.6 & 8.2 & 7.7 & 7.2 & 7.1 & 6.4 \\
\hline
\end{tabular}

Source: Czech Statistical Office.

High world market prices affected mainly industries producing materials and energy. Over 2004, prices of coke and refined oil products rose by $45.5 \%$, prices of metals and steel products by $28.9 \%$. Energy prices increased by $13.3 \%$, and prices of intermediary products by $11 \%$ - while the whole PPI index indicated growth by $7.7 \%$.

In 2004, fast pass-through of high raw material- and metal prices into prices of final investment goods, and, mainly, of consumer goods was prevented by strong competition. Also, Czech producers of steel products rapidly increased their exports, so that part of inflation was "exported" to other countries. However, the spillover effect was only temporarily dampened. While oil prices influence manufacturing with a delay of only two to four weeks, price increases in manufacturing due to steel and similar inputs come with a delay of two to three quarters. Thus it can be expected that the 2004 high level of producer prices will negatively influence consumer prices in the second half of 2005.

In 2005, prices of some raw materials and metals have started to decrease moderately, so that the peak of their growth is probably behind us. However, due to continuing high demand, and instability in some oil-producing countries, the price of oil will remain above the $55 \mathrm{USD}$ /barrel level for a longer time. We therefore expect the producer price inflation to be around of 2.0 in the Czech Republic at the end of 2005.

\section{Monetary Policy and Exchange Rate}

Over the last four years, the Czech koruna has been appreciating, both against the EUR and the USD (see Table 12). In relation to the USD, appreciation was fast and continuous. Against the euro, it was different: the CZK became almost $10 \%$ stronger during 2002, and kept near the 2002 level in the following two years (with some fluctuations, of course). Stability of nominal exchange rate toward the euro was one of the factors behind the revival of Czech exports seen since the end of 2003.

However, since September 2004 the Czech currency again started to appreciate against the euro. Some good macroeconomic figures (GDP growth, falling inflation, low interest rates, and strong export growth), together with the psychological effect 
Table 12

Exchange Rates $\left(2001-2004^{1)}\right)$

\begin{tabular}{|l|l|l|l|l|}
\hline & 2001 & 2002 & 2003 & 2004 \\
\hline CZK/EUR & 34.10 & 30.81 & 31.84 & 31.90 \\
\hline CZK/USD & 38.00 & 32.74 & 28.23 & 25.70 \\
\hline
\end{tabular}

1) Yearly averages.

Source: Czech National Bank.

Table 13

Exchange Rates (Q4/2004 - Q1/2005')

\begin{tabular}{|l|c|c|c|c|c|c|}
\hline & $10 / 2004$ & $11 / 2004$ & $12 / 2004$ & $1 / 2005$ & $2 / 2005$ & $3 / 2005$ \\
\hline CZK/EUR & 31.48 & 31.29 & 30.65 & 30.31 & 29.96 & 29.78 \\
\hline CZK/USD & 25.23 & 24.09 & 22.87 & 23.10 & 23.02 & 22.58 \\
\hline
\end{tabular}

3) Monthly averages.

Source: Czech National Bank.

of EU entry, had more impact than some other indicators that were negative - deficits of public finance and high (as well as persistent) unemployment. Appreciation of CZK against the dollar was even faster. That appreciation was able, in the recent two quarters, partly to neutralize the sizable increase of oil prices and prices of other raw materials (namely metals) in the world markets. It is to be noted that in the last months, the Czech koruna appreciated more than the euro against the dollar.

Average interest rates in the Czech Republic were in 200430 - 40 basis points above those in the euro zone (measured by 3M Euribor and Pribor). After a short rise of interest rates at the end of 2004 - to 50 basis points above Euribor - the first months of 2005, however, brought a relative fast fall of 3M Pribor. In March and April 2005, 3M Pribor has practically copied the level of 3M Euribor. Abundant liquidity in Czech banks, and a highly competitive environment, are the main factors of this situation beneficial for Czech firms and households.

Czech National Bank cut the basic repo rate three times during the first four months of 2005 (at the end of January, at the end of March and in April). After three quarters, CNB basic rate has thus returned to $1.75 \%, 25$ basis points under the ECB basic rate. Cuts in the repo rate have not influenced the exchange rate - the koruna did not react by a weakening.

Repo rate cuts by the CNB are interesting in one aspect: since the second half of 2003, the CNB in Inflation Reports repeatedly forecasted closing of the output gap, and a possible rise of future inflation. That indicated a rise in the repo rate, which indeed came in the first half of 2004. However, since the autumn of 2004, the CNB's rhetoric changed abruptly - without a closer explanation. The estimate of potential product level was raised, and the CNB started to cut rates, instead of increasing them.

As the CNB does not publish detailed information on its methods of estimating the potential product, or the output gap, ${ }^{1)}$ no one knows what the reason was for such

1) Leaving aside the problematic nature of such estimates, see, e.g., ECB, The (Un)reliability of Output Gap Estimates in Real Time, ECB Monthly Bulletin, February 2005. 
fundamental turn in CNB's stance. Was it a new, more realistic evaluation of positive changes on the supply side of the economy - or a new method of output gap estimates? Definitely, it can be said that more openness on the part of the CNB would, in this case, contribute to higher transparency of its monetary policy.

\section{Outlook}

We expect 2005 to be a year of low interest rates. Interest rates in the Czech Republic will either copy the level of the euro zone, or be under to 20 basis points above, at maximum.

Exchange rate against the euro will move within the interval of $29.50-30.50$ CZK/EUR. External shocks excluded, Czech currency could temporarily weaken at the end of the second quarter of 2005 (due to profit repatriation by foreign investors), in the same extent as last year (0.3 to $0.4 \mathrm{CZK})$. Thereafter, it would return to the longer-term trend of $3-4 \%$ yearly appreciation.

In all probability, the Czech National Bank will keep interest rates unchanged over the next 2 or 3 quarters. Appreciating currency, relative good growth and exports figures, and low inflation will support the "wait and see" stance. Possible adjustment in CNB's interest rates may thus be expected in the first quarter of 2006, depending on a rate change by the ECB.

\section{Labour Market}

First months of 2004 registered continuing deterioration on the labour market. In February 2004, the unemployment rate amounted to its historically highest level of $10.9 \%$. Second half of the year indicated stabilization of the situation. In December 2004, the unemployment rate ended on exactly the same level as a year before. First months of 2005 show first signs of improvement. As of July 2004, the unemployment rate figures have been affected by the change of methodology.

Ministry of Labour and Social Affairs changed the methodology of labour market data as of July 2004, in accordance with the ILO and Eurostat practice. The unemployment is newly specified as the number of unemployed, immediately able to accept a new job, excluding thus woman on maternity leave, soldiers, prisoners, unemployed attending requalification courses and some other minor categories. Regarding all these changes, the number of unemployed (and nominator of the unemployment rate indicator) is lower in the new methodology. On the other hand, denominator of the unemployment rate is newly higher in the new methodology, total labour force including also working and unemployed EU citizens and non-EU working labour force with valid permission for employment or entrepreneurship.

Therefore, the rate of unemployment stood at $9.2 \%$ according to the new methodology and at $10.1 \%$ in the old one, in July 2004. Figure 11 shows the differences between old and new figures. At the end of 2004, the unemployment rate reached $9.5 \%$ according to the new methodology and $10.3 \%$ under the old one. First months of 2005 registered a decline of the unemployment rate to $9.4 \%$ in March 2005. March figure represents favourable improvement also in year over year comparison: according to the old methodology the unemployment rate declined to $10.3 \%$ down from $10.7 \%$ a year earlier.

Recent moderate improvement shows that strong economic activity has affected the labour market favourably with a time lag. In particular, the situation in industry which was the main contributor of the increasing unemployment in previous years has stabilised. Strong economic activity has been supporting the creation of new 
jobs. While the vacancies were - more or less - stagnating during 2003 , their offer recovered in 2004, especially in the second half of the year.

The number of unemployed amounted to 540 thousands at the end of March 2005 , a decline by almost 20 thousands from a year earlier was thus observed. Decline of unemployment accompanied by the growth of vacancies has been improving the ratio between unemployed and vacancies. In March 2004, 10 unemployed fell upon one vacancy, while there were 13 persons a year before - see Figure 12 .

Figure 11

Unemployment Rate: Old and New Methodology

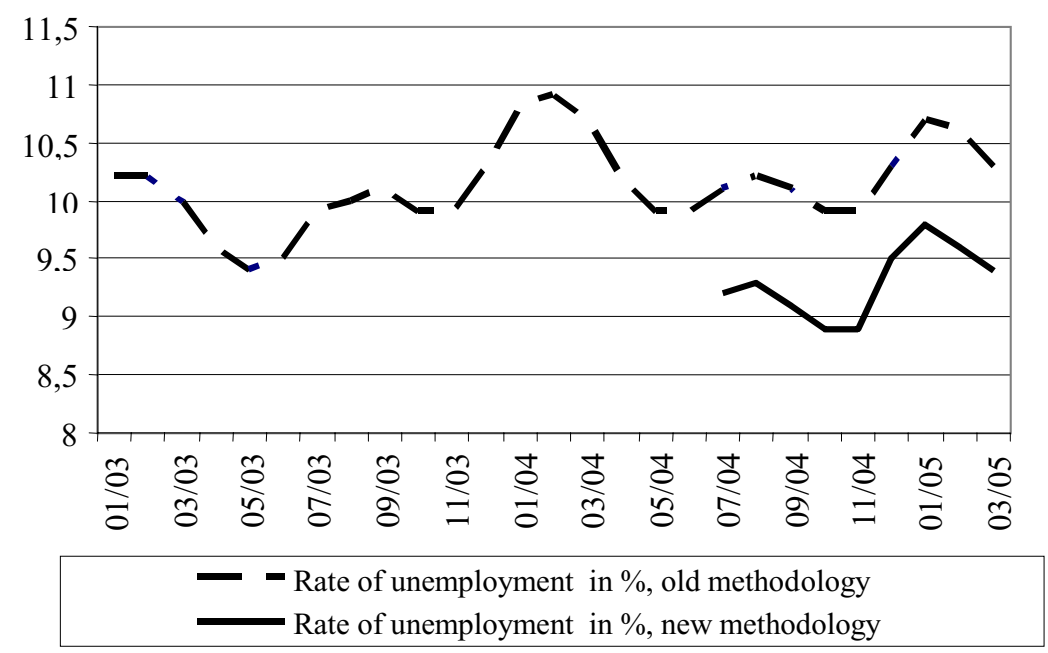

Source: Ministry of Lamour and Social Affairs.

Figure 12

Unemployed, Vacancies, UV Ratio ${ }^{5)}$

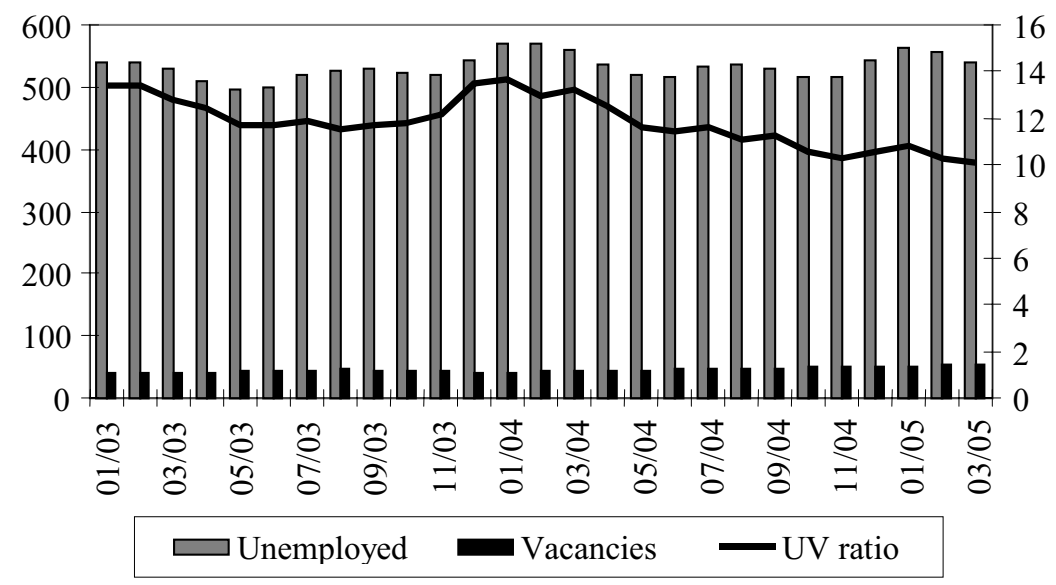

Source: Ministry of Labour and Social Affairs.

5) Unemployed and Vacancies: in thousands.

UV ratio: number of unemployed falling upon one vacancy. 
The position of the Czech Republic in international comparison is not unfavourable. Comparisons with other countries must be based on comparable data published by the Eurostat. The Eurostat's methodology sets the Czech unemployment rate to even slightly lower level than the ILO's one (which is the official domestic one as of July 2004). The Eurostat sets the Czech unemployment rate to $8.7 \%$, slightly below the EU 25 average. Within the Visegrad countries, Hungary still keeps the best position. However, the unemployment rate in Poland and Slovakia is roughly double than the Czech one.

Figure 13

Rate of Unemployment (in \%)

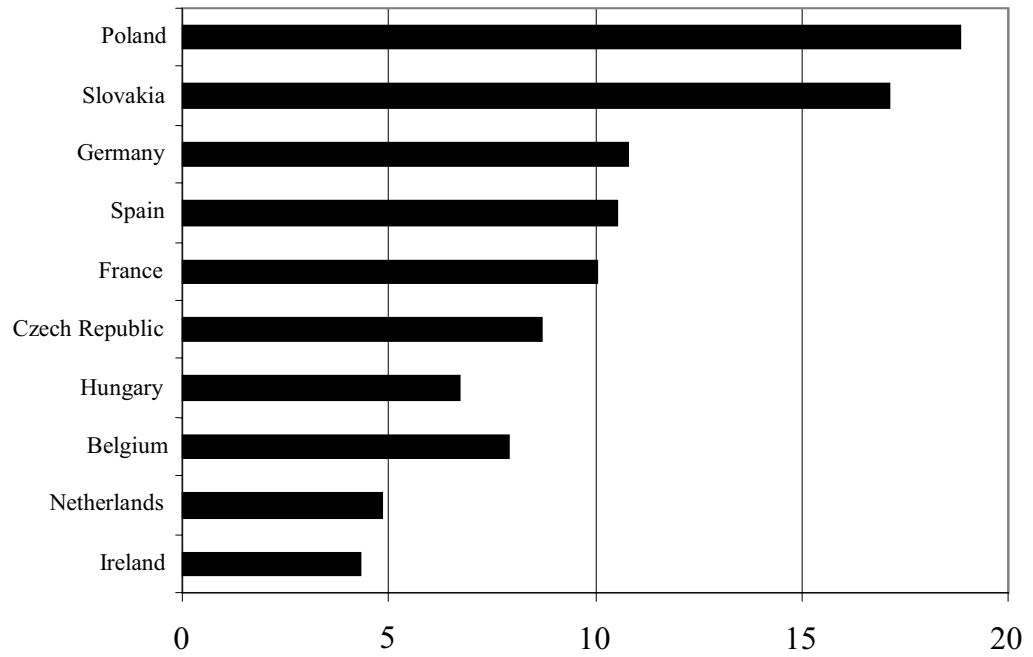

Source: Eurostat.

Nominal wages increased by $6.6 \%$ in 2004 , which was almost the same growth as a year before. However, higher inflation hit the growth of real wages, therefore, the growth of real wage registered a notable slowdown to $3.7 \%$. This has been the weakest figure since 2001 (see Table 14). Average wage before taxation amounted to CZK 18,035. Contrary to 2003, the growth of wages was more rapid in the business sector $(6.9 \%)$ than in the public one $(5.7 \%)$. Slowdown of real wages affected growth in retail trade and overall consumer demand.

Table 14

Growth of Nominal and Real Wages (growth rates in \%)

\begin{tabular}{|l|c|c|c|c|}
\hline & 2001 & 2002 & 2003 & 2004 \\
\hline Nominal wages & 8.7 & 7.2 & 6.8 & 6.6 \\
\hline Real wages & 3.8 & 5.3 & 6.7 & 3.7 \\
\hline
\end{tabular}

\section{Outlook}

In the first quarter of 2005 , the labour market finally registered a slight improvement. In the rest of the year, moderate improvement will continue as a consequence of strong economic activity. The consolidation of the situation in industry is help- 
ful for the overall employment conditions. Due to demographic developments, the new wave of graduates entering the labour market should not be very strong in 2005.

In the course of 2005, we expect regular seasonal developments. The decline of the unemployment rate in spring will be replaced by the increase in summer months (as a consequence of school-leavers entering the labour market). Later on, slight autumn decline will be followed by notable December increase due to finishing term contracts. The rate of unemployment will be slightly under $9 \%$ at the end of 2005 .

However, unemployment will remain one of the main macroeconomic bottlenecks. The scope of long-term unemployment and marginalised labour force has been continuously increasing. Flexibility of the labour market is low and the improvement may come only after adoption of measures focused in particular on higher activity of the unemployed and higher flexibility of labour contracts. At the same time, rigidity of the labour market has been supported by non-performing market with rental housing. 